\title{
AN IDIOMATIC EXPRESSION ANALYSIS ON AN AUTHENTIC MATERIAL "PRIDE AND PREJUDICE MOVIE" A MOVIE FROM JANE AUSTEN BOOK
}

\author{
Eka Sonia \\ IAIN Langsa \\ Sweetcream500@gmail.com \\ Dessy Kurniasy \\ IAIN Langsa \\ dkurniasy@gmail.com
}

\section{ABSTRACT}

The study was aimed to find and analyzed about how many idiom consist in Pride and Prejudice (2005) Movie, what are the meanings of idiom in Pride and Prejudice (2005). The data was taken from dialog line of the actor and actresses in the Pride and Prejudice (2005) where it was the script of the movie. Research design in this study was descriptive qualitative research. The technique used by the writer to collect the data was documentation. The finding showed that there are four classifications of idiom according to the Moon in Mabruroh (2015); those are transparent idioms, semi-transparent idioms, semi-opaque idioms, and opaque idioms. Transparent idioms are those idioms which are easy to comprehend its constituent meaning. Semi-transparent idioms are the idioms that usually have metaphorical meaning and their constituent parts have a little role in comprehending the whole meaning of the expression. Semi-opaque idioms are the group of idioms whose figurative meaning is not related to the meaning of their constituent words, in other words, the idiomatic expression is separated into two parts; a part with literal meaning, and the other part with a figurative meaning. The last is opaque idioms which is the idioms where the literal meaning of their parts have little to do with actual sense of idiom because it has cultural reference item. Transparent idioms that has been found in the movie is about 25 idioms, semi-transparent idioms is about 20 idioms, whether semi-opaque idioms are found about 17 idioms and the last, opaque idioms that has been found in the movie is about 18 idioms.

\section{Key Words}

Idiomatic expression, Authentic Material, and Pride and Prejudice Movie 


\section{INTRODUCTION}

English is the language of the world. In the last decade, English has become the most popular foreign language used for communication among people who do not share the same first language. As Harmer (2002) points out, English is spoken by at least a quarter of the world's population. However, it is clear from the way it has grown in the last decade that this situation is about to change. It means English is really important for our life, especially for development of knowledge, science, culture, and relationship among countries.

In fact, not all of countries in the world are using English language as they second language, many country also make English language as a foreign language which is mean, English are not widely using among the nation and just being the alternative language if the foreigner of other country come in that state.

Indonesia is one of the countries that make English language as foreign language and it is not commonly used in communication among local people for daily life. Langsa is one of small city in Indonesia which is the language commonly use in this society is Acehnese and Indonesia, and then in this city, English language just becomes a formal condition at one's moment when it needed to use it. Thus, because of its status, just a few people who take it as a serious matter and other make it as a side matter to acquire. Beside of that, the fact that English language is easy to learn if it depends on the dictionary. On the other words, English language is easy to understand if the word and the meaning have the same meaning, but when it comes to literature, English language becomes hard to understand. Literature is written to perform as art and it usually has the different meaning from the real word. There are many different kinds of literature, such as poetry, plays, or novels. 
Poetry is aesthetic and rhythmic word which is conducted to have an emotional meaning. Plays are playing the act based on the written stories which are consists of dialogue or conversation. Novels are narrative prose which contains a complex story and usually take a long process of writing.

Not to elaborating about another literature form, here the writer will only focus on idioms expression to explain. Foreign learners in Langsa are unexpectedly less understandable to each idiom. In real life, there are a plenty stuff which is involving English to make people understand especially for the country where the majority of people use English, then it will include English for many aspect of their life and that is called as authentic material. Reeves (2007) states that the form of authentic material can be as the bill in a restaurant, books, academic paper, a commercial pamphlet, radio, movie/video, television, telephone, ingredient of commercial product and others that including in our aspect of life tool. In this term, what the authors are going to analyze is about the auditory category of authentic materials that is movie. Authentic material especially in movie, the idiom can be easily understood. In conclusion, idiom and authentic material are connected and it will always appear everywhere, so that the foreign learner ought to learn idiom to understand the authentic material of English.

There are many movies taken by the best seller novels which are usually provided interesting stories for readers. It will attract viewer because of the popularity of the novel. The movie which has a great composing language usually consist of idioms which is regularly used in the setting of the movies takes place or time. We can find idioms in the dialogue of the actor. 


\section{LITERATURE REVIEW}

According to Kahhar (2015), idiomatic expression is word or phrase which has specific meaning indeed possible to may have different meaning (at all.) with the meaning of word or phrase which contains in it when it is stand alone (e.g.: from the horse's mouth; an information came from the main source. You must believe the news, I got it straight from the horse's mouth).

Idiomatic expression comes from many cultures to determine which idiom comes from what culture and know its origin. It is not easy to recognize where idiom comes from but not all of it hard to be known, some idioms are also easy to recognize its origin. It is Pearsall Smith who pointed out that there are a number of idiomatic phrases for which even specialists have not been able to find a completely certain explanation. Moreover, there may be a problem of the connection between the origin and the current use (Collins: 1958). Hence, we can say that idiomatic expression is part of figurative language which has different meaning from its literary word and the words are connected or stand alone with or without irrelevant grammar that also close to slang phrases, where the word has or not been known its origin.

\section{RESEARCH METODOLOGY}

The data on this library research will be collecting by finding information through books, magazines, newspapers and other literatures that aims to form a theoretical foundation (Arikunto, 2006). Qualitative approach was used to describe this research deeply (Moleong, 2006). Its value is based on the premise that problems can be solved and practice improved through observation, analysis, and description. Using this kind of research to this study of the "Pride and Prejudice (2005)" movie, the researchers wanted to 
give the result after having some procedures of descriptive research which is observation the movie, analysis the idiom in the dialog of the movie, and write the result into the descriptive way.

The primary data of this study were taken from the movie script of "Pride and Prejudice (2005)" which was used as the documentation as well, and the secondary data were taken from some books that describe about idioms (Sugiyono, 2016).

\section{FINDINGS AND DISCUSSIONS}

After finding the results on this research, there are several points that can be figure out of the idioms such as listening at the door, design in, not if I can help it, a long way from, let alone, my lightness of foot, to lavish upon one's partner, snap him up, the violence of my affections, turned down, no earthy reason, false modesty, fallen sister, turn us out, catch my breath, laid on that wretched man, not posses equal frankness, once in your life, out of your sense, pay him back, send them in are categorized as transparent idioms. According to Moon in Mabruroh (2015), transparent idioms are those idioms which are easy to comprehend, translate and their meaning can be derived from the meaning of their constituent parts. It can be seen from the idioms above such as: listening at the door. The word 'listening' has the literal meaning and the word 'at the door' also has literal meaning which is easy to comprehend.

The idioms such as poor nerves, count your blessing, put paid to it, positively medieval, do dote on, my humble dwelling, bound to pay, captured my special attention, a laughingstock, owe me a fortune, she's blooming, a credit to his profession, poor foot soldier, cold greeting, twice the man Darcy is, headstrong, little hiccup dealt immediately, quite a slave to your education, 
before he's cold in his grave, took the trouble of coming so far are categorized as semi-transparent idioms. According to Moon as cited in Mabruroh (2015) says that semi transparent idioms have metaphorical meaning and their constituent parts have a little role in comprehending the whole meaning of the expression. It can be seen from the idioms above such as: cold greeting, the word cold has metaphorical meaning and the word greeting is the constituent part that comprehends the whole meaning of expression.

In addition, the idioms such as let at last, catch your eye, watch your tongue, little standing, my blossom, fail to my lot, get in your way, the order of the day, I'm lost, rather grey, accepting of my hand, may I see you back, out of their sight, to the meanings of their constituent words, in other words, what on earth are categorized as semi-opaque idioms. According to Moon as cited in Mabruroh (2015) claims that semi opaque idioms is the groups of idioms whose figurative meaning is not related to the meanings of their constituent words, in the words, the idiomatic expression is separated in two parts; a part with literal meaning, and the other part with a figurative meaning. It can be seen from the idioms above such as: let at last, the word 'let' has figurative meaning and the word 'at last' has literal meaning.

Furthermore, the idioms such as good heavens, poppy cocks, the painted peacocks, take the veil, kill it stone dead, all the world, without a roof over their head, nor a penny to their name, six inches deep in mud, breathtaking, to the censure of the world for caprice, very thin on the ground, eaten up, grave indeed, a bowl of punch, I've been so blind, heaven and earth are categorized as opaque idioms. According to Moon as cited in Mabruroh (2015) mentions that opaque idioms are the most difficult type of idioms because the literal meaning of their parts have little to do with the actual 
sense of idioms, that is, the meaning of an opaque idiom cannot be derived from the meanings of its individual parts because there are items which have cultural reference. It can be seen from the idioms above such as poppy cocks, the word poppy cocks has cultural reference meaning.

\section{CONCLUSIONS}

The conclusions of this research are as follows:

1. There are 80 idioms in the movie script of Pride and Prejudice (2005). Those idioms can be categorized into transparent, semitransparent, and opaque idiom.

2. The meaning of the idioms are as follows:

1) 'Let at last' means finally has been rent.

2) 'Listening at the door' means listening to other conversation in secret.

3) 'Design in' means goal/purpose.

4) 'Good heavens' means oh god.

5) 'Poor nerve' means mentality.

6) 'Poppy cock' means non-sensible man/woman.

7) 'Catch your eye' means interesting to see.

8) 'Watch your tongue' means speaks carefully.

9) 'The painted peacocks' means a noble man/ noble woman who like to wear beautiful thing.

10) 'Take the veil' means become a nun.

11) 'Not if I can help it' means a polite way of saying no/rejection.

12) 'A long way' from means different economy status from.

13) 'Count your blessings' means be grateful.

14) 'Let alone' means let it go. 
15) 'Put paid to it' means finish something off.

16) 'Kill it stone dead' means destroy something utterly.

17) 'All the world' means everything.

18) 'Little standing' means low status in society.

19) 'Without a roof over their head' means have no place to live.

20) 'Nor a penny to their name' means have no money/ very poor person.

21) 'Six inches deep in mud' means very dirty.

22) 'Positively medieval' means country bumpkin person.

23) 'My blossom' means dear.

24) 'Fall to my lot' means my job/ duty.

25) 'Do dote on' means love or ardently.

26) 'Not room enough to do them justice' means have no space.

27) 'Get in your' way means get away.

28) 'For heaven's sake' means oh my god

29) 'The order of the day' means the important things to do.

30) 'My humble dwelling' means a flat house or a standard house.

31) 'Bound to pay' means very useful things to do.

32) 'Captured my special attention' means interested in.

33) 'I'm lost' means have no idea.

34) 'A laughing stock' means a bullied person because he/she always do stupid thing.

35) 'Owe me a fortune' means owe a lot of money from other person.

36) 'She's blooming' means blushing.

37) 'A credit to his profession' means honour to job.

38) 'Poor foot soldier' means infantry soldier. 
39) 'Cold greeting' means do not care about each other.

40) 'Think ill of anybody' means think bad to a person or more.

41) 'Twice the man Darcy' means better than Darcy.

42) 'Breath-taking' means spectacular.

43) 'My lightness of foot' means a good dancer.

44) 'To lavish upon one's partner' means give so many things to other person in other to gain their affections.

45) 'Throw her sisters in the way of other rich men' means many her sisters get other rich man to marry.

46) 'Snap him up' means get someone fast.

47) 'The violence of my affections' means bad love actions.

48) 'Headstrong' means someone who had strong opinion about something.

49) 'Little hiccup dealt immediately' means a small problem to solve fast.

50) 'Turned down' means rejecting.

51) 'No earthly reason' means not have a specific reason.

52) 'Rather grey' means dull.

53) 'Quite a slave to your education' means ignore on education.

54) 'False modesty' means pretend holding a humble opinion oneself to encourage other people.

55) 'Accepting of my hand' means ask to marry someone.

56) 'To the censure of the world for caprice' means egoism person who involved in other person matter.

57) 'Very thin on the ground' means abundant/ not plentiful.

58) 'Eaten up' means thoroughly enjoy something. 
59) 'May I see you back' means asking to send someone to where she stayed.

60) 'You had painted him' means describing other person character to other.

61) 'Grave indeed' means also mourned of other person disaster or experience.

62) 'Out of their sight' means uncontrollable.

63) 'Fallen sister' means a girl who ruined up her reputation in the society.

64) 'Turn us out' means make someone leave their place.

65) 'Before he's cold in his grave' means someone that has just died.

66) 'Catch my breath' means take a rest for a while.

67) 'Laid on that wretched man' means depend on someone who bribed blasted man.

68) 'A bowl of punch' means a big feast with fancy.

69) 'I've been so blind' means not seeing the truth.

70) 'No doubt poisoned by his pernicious sister' means persuaded to choose a bad way by someone close to him.

71) 'Took the trouble of coming so far' means want to solve an urgent thing immediately.

72) 'Not possess equal frankness' means not the same rude.

73) 'Heaven and Earth' means oh my goodness.

74) 'Are the shades of Pemberley to be thus polluted' means intermarriage with someone deemed un-worthy.

75) 'What on earth' means what has happened.

76) 'Once in your life' means just for a moment.

77) 'Bewitched me, body, and soul' means in love with me. 
78) 'Out of your senses' means crazy or out of mind.

79) 'Pay him back' means repay one's kindness.

80) 'Send them in' means asking to make someone entering a room.

\section{REFERENCE}

Arikunto, S. (2006). Prosedur penelitian: Suatu pendekatan praktek. Jakarta: PT. Rineka Cipta.

Collins, H.V. (1958). A book of English idiom (Third Edition). London: Longman Group Limited.

Harmer, J. (2002). The practice of English language teaching (Fourth Edition). England: Longman.

Kahhar, S. (2015) Idiom bahasa Inggris. Indonesia: Cemerlang Publishing.

Mabruroh, K. (n.d). An analysis of idioms and their problems found in the novel the adventures of Tom Sawyer by Mark Twain. Rainbow: Journal of Literature, Linguistics and Cultural Studies, 4(1).

Moleong, J. L. (2006). Metode penelitian kualitatif, Edisi Revisi. Bandung: Remaja Rosda Karya.

Reeves, A. (2007). Authentic materials final . USA: American Institute for research.

Sugiono. (2016). Metode Penelitian Kuantitatif, Kualitatif, dan R\&D. Bandung: Alfabeta. 